\title{
Carbon-isotope discrimination by leaves of Flaveria species exhibiting different amounts of $\mathrm{C}_{3}$ - and $\mathrm{C}_{4}$-cycle co-function
}

\author{
R.K. Monson ${ }^{1 *}$, J.A. Teeri ${ }^{2 * *}$, M.S.B. Ku ${ }^{3}$, J. Gurevitch ${ }^{4}$, L.J. Mets $^{2}$ and S. Dudley $^{2}$ \\ ${ }^{1}$ Department of Environmental, Population and Organismic Biology, Campus Box 334, University of Colorado, Boulder, \\ CO 80309 , \\ ${ }^{2}$ Barnes Laboratory, University of Chicago, 5630 South Ingleside Avenue, Chicago, IL 60637, \\ ${ }^{3}$ Department of Botany, Washington State University, Pullman, WA 99164, and \\ ${ }^{4}$ Department of Ecology and Evolution, State University of New York, Stony Brook, NY 11794, USA
}

\begin{abstract}
Carbon-isotope ratios were examined as $\delta^{13} \mathrm{C}$ values in several $\mathrm{C}_{3}, \mathrm{C}_{4}$, and $\mathrm{C}_{3}-\mathrm{C}_{4}$ Flaveria species, and compared to predicted $\delta^{13} \mathrm{C}$ values generated from theoretical models. The measured $\delta^{13} \mathrm{C}$ values were within $4 \%$ of those predicted from the models. The models were used to identify factors that contribute to $\mathrm{C}_{3}$-like $\delta^{13} \mathrm{C}$ values in $\mathrm{C}_{3}-\mathrm{C}_{4}$ species that exhibit considerable $\mathrm{C}_{4}$-cycle activity. Two of the factors contributing to $\mathrm{C}_{3}$-like $\delta^{13} \mathrm{C}$ values are high $\mathrm{CO}_{2}$ leakiness from the $\mathrm{C}_{4}$ pathway and pi/pa values that were higher than $\mathrm{C}_{4}$ congeners. A marked break occurred in the relationship between the percentage of atmospheric $\mathrm{CO}_{2}$ assimilated through the $\mathrm{C}_{4}$ cycle and the $\delta^{13} \mathrm{C}$ value. Below $50 \% \mathrm{C}_{4}$-cycle assimilation there was no significant relationship between the variables, but above $50 \%$ the $\delta^{13} \mathrm{C}$ values became less negative. These results demonstrate that the level of $\mathrm{C}_{4}$-cycle expression can increase from 0 to $50 \%$ with little integration of carbon transfer from the $\mathrm{C}_{4}$ to the $\mathrm{C}_{3}$ cycle. As expression increases above $50 \%$, however, increased integration of $\mathrm{C}_{3}-$ and $\mathrm{C}_{4}$-cycle co-function occurs.
\end{abstract}

Key words: $\mathrm{C}_{3}-\mathrm{C}_{4}$ intermediate plants - Carbon isotope discrimination (ratio, theory) - Flaveria Photosynthesis $\left(\mathrm{C}_{3}, \mathrm{C}_{4}, \mathrm{C}_{3}-\mathrm{C}_{4}\right)$.

\section{Introduction}

Species that exhibit characteristics of both the $C_{3}$ and $\mathrm{C}_{4}$ photosynthetic pathways have been the

\footnotetext{
* To whom correspondence should be addressed

** Present address: Biological Station, University of Michigan, Natural Science Building, Ann Arbor, MI 48109
}

Abbreviations and symbols: RuBP carboxylase = ribulose-1,5bisphosphate carboxylase (EC 4.1.1.39); PEP carboxylase = phosphoenolpyruvate carboxylase (EC 4.1.1.31); pa=atmospheric $\mathrm{CO}_{2}$ partial pressure; $\mathrm{pi}=$ intercellular $\mathrm{CO}_{2}$ partial pressure; $\delta=$ isotope ratio; $\phi=$ quantum yield for $\mathrm{CO}_{2}$ uptake subject of considerable recent research (see reviews by Monson et al. 1984; Holaday and Chollet 1984; Edwards and $\mathrm{Ku} 1988$ ). Such species have importance in applied disciplines, in that they might contribute knowledge towards breeding efforts to introduce $\mathrm{C}_{4}$ traits into otherwise $\mathrm{C}_{3}$ plants, and more basic disciplines, in that they might contribute knowledge to the paths taken during the evolution of $\mathrm{C}_{4}$ photosynthesis. In addition to $\mathrm{C}_{3}$ and $\mathrm{C}_{4}$ species, the genus Flaveria (Asteraceae) contains many species that exhibit anatomical and physiological traits characteristic of both the $\mathrm{C}_{3}$ and $\mathrm{C}_{4}$ syndromes ( $\mathrm{Ku}$ et al. 1983; Holaday et al. 1984; Edwards and $\mathrm{Ku} 1988$ ). Several of these $\mathrm{C}_{3}-$ $\mathrm{C}_{4}$ species assimilate atmospheric $\mathrm{CO}_{2}$ through both the $\mathrm{C}_{3}$ and $\mathrm{C}_{4}$ photosynthetic pathways (Rumpho et al. 1984; Bassüner et al. 1984; Monson et al. 1986). In a number of these species, $C_{4}$ photosynthesis can be responsible for up to $50 \%$ of the atmospheric $\mathrm{CO}_{2}$ assimilation.

Despite the biochemical evidence for considerable $\mathrm{C}_{4}$-cycle function in many of the Flaveria species, previous measurements of carbon-isotope values are suggestive of little contribution of $\mathrm{C}_{4}$ photosynthesis to growth (Smith and Turner 1975; Powell 1978; Smith and Powell 1984). The presence of $\mathrm{C}_{3}$-like carbon-isotope ratios in these otherwise intermediate plants has resulted in a paradox, since differences in the levels of atmospheric $\mathrm{CO}_{2}$ assimilation through the $\mathrm{C}_{3}$ or $\mathrm{C}_{4}$ pathways should be detectable as differences in the level of discrimination against ${ }^{13} \mathrm{CO}_{2}$. The assimilation of atmospheric $\mathrm{CO}_{2}$ through the $\mathrm{C}_{3}$ cycle will result in greater discrimination against ${ }^{13} \mathrm{C}$ and a more negative $\delta^{13} \mathrm{C}$ value, relative to $\mathrm{CO}_{2}$ assimilation through the $\mathrm{C}_{4}$ cycle (O'Leary 1981). Thus, in $\mathrm{C}_{3}$ plants, $\delta^{13} \mathrm{C}$ values between -25 and $-30 \%$ are typically measured, whereas in $\mathrm{C}_{4}$ plants the values are typically between -10 and $-16 \%$. In plants that exhibit a balance of $\mathrm{C}_{3}$ - and $\mathrm{C}_{4}$-cycle co-func- 
tion in assimilating atmospheric $\mathrm{CO}_{2}$, such as several of the Flaveria species, the $\delta^{13} \mathrm{C}$ value should be intermediate between the $\mathrm{C}_{3}$ and $\mathrm{C}_{4}$ extremes.

In a recent study, Peisker (1985) attempted to make quantitative predictions of what the $\delta^{13} \mathrm{C}$ values should be in $\mathrm{C}_{3}-\mathrm{C}_{4}$ species. His results demonstrated that $\mathrm{C}_{3}$-like $\delta^{13} \mathrm{C}$ values would result if the $\mathrm{C}_{4}$ cycle was rate-limited by factors other than phosphoenolpyruvate (PEP)-carboxylase activity, for example PEP-regeneration rate. One implication of Peisker's study is that although PEPcarboxylase activities in $\mathrm{C}_{3}-\mathrm{C}_{4}$ species are measurably higher than in $\mathrm{C}_{3}$ species, they do not accurately reflect $\mathrm{C}_{4}$-cycle assimilation of $\mathrm{CO}_{2}$. In essence, according to Peisker's model the $\mathrm{C}_{3}$-like $\delta^{13} \mathrm{C}$ values in otherwise $\mathrm{C}_{3}-\mathrm{C}_{4}$ species were attributed to a low $\mathrm{C}_{4}$-cycle activity. However, as mentioned above, recent studies with several $\mathrm{C}_{3}-$ $\mathrm{C}_{4}$ Flaveria species have demonstrated considerable potential for $\mathrm{C}_{4}$-cycle assimilation of atmospheric $\mathrm{CO}_{2}$ (Monson et al. 1986). Thus, an enigma still exists as to why $\mathrm{C}_{3}$-like $\delta^{13} \mathrm{C}$ values occur in plants with such a large fraction of $\mathrm{C}_{4}$-cycle $\mathrm{CO}_{2}$ assimilation. In this study, we have compared measured $\delta^{13} \mathrm{C}$ values with those predicted from theoretical models in order to identify factors which may be responsible for the discrepency. Such an approach has previously been used to explain why $\delta{ }^{13} \mathrm{C}$ values in fully-expressed $\mathrm{C}_{4}$ species are more negative than those predicted solely from biochemical and biophysical fractionation processes (Farquhar 1983). Our analysis showed that an inefficient transfer of $\mathrm{CO}_{2}$ from the $\mathrm{C}_{4}$ to the $\mathrm{C}_{3}$ cycle, following the decarboxylation of $\mathrm{C}_{4^{-}}$ acids, could result in $\mathrm{C}_{3}$-like $\delta^{13} \mathrm{C}$ values in the $\mathrm{C}_{3}-\mathrm{C}_{4}$ Flaveria species.

\section{Material and methods}

Plant material. Plants of all species, except Flaveria brownii A.M. Powell and F. floridana Johnson, were established from seeds obtained from Dr. A.M. Powell (Sul Ross State University, Alpine, Tex., USA). The seeds were originally collected from field populations in Mexico (see Powell 1978). Plants of F. brownii and $F$. floridana were established from seeds collected by Dr. L.J. Mets (University of Chicago, Chicago, Ill., USA) from Texas and Florida, respectively. Following establishment the plants were maintained in greenhouse or growth-chamber culture, each species being propagated from branch cuttings.

For one group of plants grown in a growth chamber, intensive studies of leaf $\delta^{13} \mathrm{C}$ values and biochemical traits were conducted (data reported in Table 1). These plants were grown in a controlled-temperature regime of $27^{\circ} \mathrm{C}$ day $/ 22^{\circ} \mathrm{C}$ night. The 14 -h light period was produced by a combination of fluorescent and incandescent lamps. The photosynthetic photon fluence rate $(400-700 \mathrm{~nm})$ at plant height was between 650 and $800 \mu \mathrm{mol} \cdot \mathrm{m}^{-2} \cdot \mathrm{s}^{-1}$. In calculating the predicted $\delta^{13} \mathrm{C}$ values reported in Table 1 , measurements of the quantum yield for $\mathrm{CO}_{2}$ uptake were required (see Theory section). Measurements of the quantum yield were conducted on established cuttings of the same plants used in the growth-chamber studies, although in this case the plants were grown in a greenhouse in Boulder, Colo. Care was taken to match the greenhouse growth conditions to those used in the growth chamber in the following ways: the quantum-yield measurements were conducted between late-May and early-August, 1985, when photoperiods ranged between 14 and $15 \mathrm{~h}$, greenhouse temperatures were maintained at $25-30^{\circ} \mathrm{C}$ during the day and $18-23^{\circ} \mathrm{C}$ during the night, and the photon fluence rate was maintained between $700-900 \mu \mathrm{mol} \cdot \mathrm{m}^{-2} \cdot \mathrm{s}^{-1}(400-700 \mathrm{~nm})$ at midday on clear days by partially shading the plants.

We assumed a value of $-7.5 \%$ for the $\delta^{13} \mathrm{C}$ of the air in the growth chamber. This is the value typically assumed for clean ambient air (Keeling et al. 1979). As a check of this value, we calculated the $\delta^{13} \mathrm{C}$ value of the growth chamber air to be $-7.4 \%$ using the measured value of $-29.4 \%$ for the $C_{3}$ plant $F$. cronquistii and equation (12) from Farquhar et al. (1982). Flaveria cronquistii exhibits a small amount of atmospheric $\mathrm{CO}_{2}$ assimilation through PEP carboxylase (Monson et al. 1986, Table 1). However, this small amount of $\mathrm{C}_{4}{ }^{-}$ cycle activity would only introduce an error of $+1.3 \%$ into the calculation of the $\delta^{13} \mathrm{C}$ value for the growth-chamber air (compare the predicted and actual $\delta^{13} \mathrm{C}$ values for $F$. cronquistii in Table 1).

Experimental methods. The combustion and analytical methods used to determine leaf- $\delta^{13} \mathrm{C}$ values were as described in Gurevitch et al. (1986). Carbon-isotope ratios were obtained for the youngest fully expanded leaves (third or fourth node from the apex) of non-flowering plants. The ${ }^{14} \mathrm{CO}_{2}$ pulse- ${ }^{12} \mathrm{CO}_{2}$ chase studies, that were used to establish the relative activities of the $\mathrm{C}_{3}$ and $\mathrm{C}_{4}$ cycles, and the gas-exchange methods used in the quantum-yield and intercellular (pi) and ambient (pa) $\mathrm{CO}_{2}$ partial pressure measurements, are described in detail in a previous paper (Monson et al. 1986). Measurements of $\mathrm{pi} / \mathrm{pa}$ were determined at a photosynthetic photon fluence rate of $1500 \mu \mathrm{mol} \cdot \mathrm{m}^{-2} \cdot \mathrm{s}^{-1}$, leaf temperature of $30^{\circ} \mathrm{C}$, and leaf-to-air water-vapor concentration gradient of $12-15 \mathrm{mmol} \cdot \mathrm{mol}^{-1}$.

\section{Theory}

Predictions of the $\delta^{13} \mathrm{C}$ values for eight Flaveria species were generated using previous biochemical and physiological measurements (Monson et al. 1986, 1987), and previously described models of carbon-isotope discrimination resulting from diffusive and biochemical fractionation (Farquhar et al. 1982; Farquhar 1983). Knowing the proportion of atmospheric $\mathrm{CO}_{2}$ assimilated by the $\mathrm{C}_{3}$ and $\mathrm{C}_{4}$ pathways, we calculated the carbon-isotope ratios of the $\mathrm{C}_{3}-\mathrm{C}_{4}$ species using the following expression:

$\delta^{13} \mathrm{C}_{\mathrm{tot}}=\left(\delta^{13} \mathrm{C}_{\mathrm{c} 4} \cdot \mathrm{c}+\delta^{13} \mathrm{C}_{\mathrm{c} 3} \cdot \mathrm{d}\right)$

where $\delta^{13} \mathrm{C}_{\text {tot }}$ is the predicted $\delta^{13} \mathrm{C}$ value for total carbon assimilated in $\mathrm{C}_{3}-\mathrm{C}_{4}$ plants, $c$ represents the proportion of atmospheric $\mathrm{CO}_{2}$ assimilated through the $\mathrm{C}_{4}$ cycle, $d$ represents the proportion of atmospheric $\mathrm{CO}_{2}$ assimilated through the $\mathrm{C}_{3}$ cycle, $\delta^{13} \mathrm{C}_{\mathrm{c} 4}$ represents the predicted $\delta^{13} \mathrm{C}$ value for carbon assimilated through the $\mathrm{C}_{4}$ pathway, 
and $\delta^{13} \mathrm{C}_{\mathrm{c} 3}$ is the predicted $\delta^{13} \mathrm{C}$ value for carbon assimilated through the $\mathrm{C}_{3}$ pathway.

The values for $\delta^{13} \mathrm{C}_{\mathrm{c} 4}$ and $\delta^{13} \mathrm{C}_{\mathrm{c} 3}$ were determined according to Eq. (11) in Farquhar (1983) and Eq. (12) in Farquhar et al. (1982), respectively. The only correction was that we used a value of $29 \%$ as the fractionation caused by ribulose-1,5bisphosphate (RuBP) carboxylase (see Roeske and O'Leary 1984). Determination of $\delta^{13} \mathrm{C}_{\mathrm{c} 4}$ requires knowledge of the leakiness $(\emptyset)$ which is the proportion of $\mathrm{CO}_{2}$ that is initially assimilated by PEP carboxylase, but not reassimilated by RuBP carboxylase following decarboxylation of the $\mathrm{C}_{4}$ acids. In this study $\emptyset$ was determined from the $\mathrm{C}_{4}$ quantum yield for $\mathrm{C}_{4}$ uptake $\left(\mathrm{q}_{4}\right)$ using the expression for $\emptyset_{2}$ in Farquhar (1983). In those species that exhibit atmospheric $\mathrm{CO}_{2}$ assimilation simultaneously through both the $\mathrm{C}_{3}$ and $\mathrm{C}_{4}$ pathways, the $\mathrm{C}_{4}$ quantum yield was calculated from the total quantum yield $\left(\mathrm{C}_{3}+\mathrm{C}_{4}\right)$ using the following expression:

$\mathrm{q}_{\text {tot }}=\left(c \cdot \mathrm{q}_{4}\right)+\left(d \cdot \mathrm{q}_{3}\right)$

where $q_{\text {tot }}$ is the total quantum yield, $q_{3}$ represents the $\mathrm{C}_{3}$ quantum yield, and $\mathrm{q}_{4}$ represents the $\mathrm{C}_{4}$ quantum yield. Assuming the $\mathrm{C}_{3}$ quantum yield to be $0.052 \mathrm{~mol} \mathrm{CO} \mathrm{CO}_{2} \cdot \mathrm{mol}^{-1}$ quanta absorbed at $25-30^{\circ} \mathrm{C}$ (determined as the mean of over 30 species, see Ehleringer and Björkman 1977; Monson et al. 1982; Ehleringer and Pearcy 1983), Eq. (2) can be rearranged to:

$\mathrm{q}_{4}=\left(\mathrm{q}_{\text {tot }}-d \cdot 0.052\right) / c$

In all species, except $F$. trinervia, the values for $d$ and $c$ were determined from 8 -s ${ }^{14} \mathrm{CO}_{2}$-pulse experiments (Monson et al. 1986). Ideally, the values for $c$ and $d$ should be determined from pulse experiments of varying duration, that can be used to extrapolate to a pulse-time equal to zero. To date, the latter type of measurement has only been conducted with two $\mathrm{C}_{3}-\mathrm{C}_{4}$ species. $F$. pubescens (Bassüner et al. 1984) and $F$. ramosissima (Rumpho et al. 1984), and one $\mathrm{C}_{4}$ species, $F$. trinervia (Rumpho et al. 1984). The studies with the $\mathrm{C}_{3}-\mathrm{C}_{4}$ species revealed little change in the proportion of the ${ }^{14} \mathrm{C}$ recovered from $\mathrm{C}_{3}$ and $\mathrm{C}_{4}$ products between 0 and $10 \mathrm{~s}$, demonstrating that the use of the previous 8-s pulse data (Monson et al. 1986) for the $c$ and $d$ values is reasonable in the $\mathrm{C}_{3}-\mathrm{C}_{4}$ species. In the $\mathrm{C}_{4}$ species $F$. trinervia, data from ${ }^{14} \mathrm{CO}_{2}$-pulse experiments of varying durations revealed that approximately $100 \%$ of atmospheric $\mathrm{CO}_{2}$ is assimilated through the $\mathrm{C}_{4}$ pathway at a time equal to 0 . Therefore, we have used 1.0 for $c$ in the calculations of predicted $\delta^{13} \mathrm{C}$ for this species.
In theory, it is an oversimplification to treat the $\mathrm{C}_{3}$ and $\mathrm{C}_{4}$ pathways as isotopically separate, since previous observations have shown RuBP carboxylase and PEP carboxylase to be in both mesophyll and bundle-sheath cells in some $\mathrm{C}_{3}-\mathrm{C}_{4}$ Flaveria species (Bauwe 1984; Reed and Chollet 1985). Thus, both carboxylases are drawing upon the same intercellular pool of $\mathrm{CO}_{2}$, and the potential exists for carbon-isotope discrimination by one to influence discrimination by the other. Such an influence will occur because the $\delta^{13} \mathrm{C}$ value of the intercellular $\mathrm{CO}_{2}$ pool will be adjusted to some value different from that expected in fully expressed $\mathrm{C}_{3}$ and $\mathrm{C}_{4}$ plants. In essence, such an adjustment can be considered as an extra discrimination factor since it acts to alter the ${ }^{13} \mathrm{C} /{ }^{12} \mathrm{C}$ ratio of the intercellular $\mathrm{CO}_{2}$, just as with other discrimination. We examined the magnitude of this effect using equations described in O'Leary (1981) to calculate the $\delta^{13} \mathrm{C}$ value of the intercellular $\mathrm{CO}_{2}$ pool in $\mathrm{C}_{3}-\mathrm{C}_{4}$ species. Since the discrimination caused by the carboxylases is characterized by different signs (RuBP carboxylase discriminates against ${ }^{13} \mathrm{C}$, whereas the combined effect of equilibration between $\mathrm{CO}_{2}$ and $\mathrm{HCO}_{3}^{-}$and discrimination by PEP carboxylase favors the assimilation of ${ }^{13} \mathrm{C}$ ), to some extent the discrimination by one compensates for the discrimination by the other. For example, in $\mathrm{C}_{3}-\mathrm{C}_{4}$ species with nearly equal amounts of atmospheric carbon assimilated through the $\mathrm{C}_{3}$ and $\mathrm{C}_{4}$ cycles, we estimate that the presence of RuBP carboxylase in the mesophyll cells causes carbon assimilated by PEP carboxylase to be enriched in ${ }^{13} \mathrm{C}$ by approx. $9 \%$, compared to fully expressed $\mathrm{C}_{4}$ plants. Conversely, the presence of PEP carboxylase in the mesophyll cells, causes carbon assimilated by RuBP carboxylase to be enriched in ${ }^{12} \mathrm{C}$ by approx. $6 \%$, compared to fully expressed $\mathrm{C}_{3}$ plants. When the $\delta^{13} \mathrm{C}_{\text {tot }}$ is calculated for such $\mathrm{C}_{3}-\mathrm{C}_{4}$ species, these differences translate into an error of only $1-2 \%$ by not considering the effect of discrimination by one carboxylase on discrimination by the other. We have not presented this analysis in a formal manner, since it should only be taken as a first approximation. More elegant modelling efforts should be conducted to accurately describe the effects of co-discrimination by the decarboxylases. Nonetheless, at first consideration the effect appears to be small.

\section{Results}

In one set of measurements the proportion of $\mathrm{CO}_{2}$ assimilated through the $\mathrm{C}_{3}$ and $\mathrm{C}_{4}$ cycles was mea- 
Table 1. Actual and predicted $\delta^{13} \mathrm{C}$ values for growth-chamber-grown plants and the parameters used to calculate the predicted $\delta^{13} \mathrm{C}$ values (see Theory section for calculation procedure) in nine Flaveria species

\begin{tabular}{|c|c|c|c|c|c|c|c|c|}
\hline Species & $\begin{array}{l}\text { Photo- } \\
\text { synthetic } \\
\text { pathway }\end{array}$ & $c$ & $d$ & $\begin{array}{l}\mathrm{q}_{\mathrm{tot}} \\
\left(\mathrm{mol} \mathrm{CO}_{2}\right. \\
\left.(\mathrm{mol} \text { quanta })^{-1}\right)\end{array}$ & $\emptyset_{2}$ & $\mathrm{pi} / \mathrm{pa}$ & $\begin{array}{l}\text { Predicted } \\
\delta^{13} \mathrm{C} \\
(\%)\end{array}$ & $\begin{array}{l}\text { Actual } \\
\delta^{13} \mathrm{C} \\
(\%)\end{array}$ \\
\hline F. cronquistii Powell & $\mathrm{C}_{3}$ & 0.14 & 0.86 & 0.053 & 0.71 & 0.735 & -28.1 & -29.4 \\
\hline F. linearis Lag. & $\mathrm{C}_{3}-\mathrm{C}_{4}$ & 0.23 & 0.77 & 0.050 & 0.79 & 0.737 & -28.0 & -27.9 \\
\hline F. pubescens Rydb. & $\mathrm{C}_{3}-\mathrm{C}_{4}$ & 0.41 & 0.59 & 0.044 & 0.86 & 0.779 & -28.0 & -28.3 \\
\hline F. anomala Robinson & $\mathrm{C}_{3}-\mathrm{C}_{4}$ & 0.44 & 0.56 & 0.051 & 0.73 & 0.760 & -26.1 & -28.3 \\
\hline F. ramosissima Klatt & $\mathrm{C}_{3}-\mathrm{C}_{4}$ & 0.49 & 0.51 & 0.052 & 0.71 & 0.765 & -25.4 & -28.5 \\
\hline F. floridana Johnson & $\mathrm{C}_{3}-\mathrm{C}_{4}$ & 0.52 & 0.48 & 0.046 & 0.81 & 0.766 & -26.2 & -29.9 \\
\hline F. brownii A.M. Powell & $\mathrm{C}_{3}-\mathrm{C}_{4}$ & 0.65 & 0.35 & 0.052 & 0.73 & 0.482 & -19.5 & -17.4 \\
\hline F. palmeri Johnson & $\mathrm{C}_{4}$ & 0.76 & 0.24 & ND & ND & ND & ND & -16.5 \\
\hline $\begin{array}{l}\text { F. trinervia (Spreng.) } \\
\text { Mohr }\end{array}$ & $\mathrm{C}_{4}$ & 1.00 & 0 & 0.051 & 0.72 & 0.441 & -16.6 & -14.3 \\
\hline
\end{tabular}

Actual $\delta^{13} \mathrm{C}$ values for $F$. brownii and $F$. palmeri were determined from greenhouse-grown plants, all others were from the same growth-chamber-grown plants used for determining $c$ and $d$

$c$ and $d$ represent the percentages of atmospheric $\mathrm{CO}_{2}$ assimilated through the $\mathrm{C}_{4}$ and $\mathrm{C}_{3}$ photosynthetic pathways, respectively. These data were taken from Monson et al. (1986)

$\mathrm{q}_{\text {tot }}$ represents the total quantum yield $\left(\mathrm{C}_{4}+\mathrm{C}_{3}\right)$, which were also taken from Monson et al. (1986)

$\emptyset_{2}$ represents the $\mathrm{CO}_{2}$ leakiness values

$\mathrm{pi} /$ pa represents the ratio of intercellular (pi) to ambient (pa) $\mathrm{CO}_{2}$ partial pressures

$\mathrm{ND}=$ not determined

sured directly using ${ }^{14} \mathrm{CO}_{2}$ pulse- ${ }^{12} \mathrm{CO}_{2}$ chase techniques and these proportions, along with measurements of the quantum yield for $\mathrm{CO}_{2}$ uptake and $\mathrm{pi} / \mathrm{pa}$, were used to calculate the predicted $\delta^{13} \mathrm{C}$ values for eight species (see Table 1 ). Leaves from the same plants were harvested and used for actual carbon-isotope measurements. Thus, direct comparisons could be made between predicted $\delta^{13} \mathrm{C}$ values and actual $\delta^{13} \mathrm{C}$ values. Calculations of $\mathrm{CO}_{2}$ leakiness from the $\mathrm{C}_{4}$ cycle $\left(\emptyset_{2}\right)$ revealed relatively high values for all of the Flaveria species that we examined. Even for the fully expressed $\mathrm{C}_{4}$ plant, $F$. trinervia, leakiness values were estimated to be 0.72 . Values for $\mathrm{pi} / \mathrm{pa}$ were much lower in the $\mathrm{C}_{4}$ species, $F$. trinervia, and the $\mathrm{C}_{3}-\mathrm{C}_{4}$ species, $F$. brownii, relative to the $\mathrm{C}_{3}$ species $F$. cronquistii. The other five $\mathrm{C}_{3}-\mathrm{C}_{4}$ species exhibited similar, or slightly higher, pi/pa values relative to $F$. cronquistii. In this study we have treated $F$. cronquistii as a $C_{3}$ species for purposes of classification in Table 1. However, previous pulse-chase studies have shown that, following an 8-s pulse with ${ }^{14} \mathrm{CO}_{2}$, approx. $14 \%$ of the assimilated ${ }^{14} \mathrm{C}$ can be recovered in $\mathrm{C}_{4}$-acids (Monson et al. 1986). A considerable portion of the $\mathrm{C}_{4}$-acid synthesis was accounted for by non-photosynthetic processes (Monson et al. 1986). Nonetheless, we have calculated a leakiness value for this $\mathrm{C}_{4}$-cycle activity, and using it predicted a $\delta^{13} \mathrm{C}$ value of $-28.1 \%$. The latter value is only $1.3 \%$ less negative than the actual value of $-29.4 \%$. However, the uncertain nature of $\mathrm{C}_{4}$ assimilation in this species, and its influence on the $\delta^{13} \mathrm{C}$ value, should be noted. The $\mathrm{C}_{3}-\mathrm{C}_{4}$ species were predicted to exhibit $\delta^{13} \mathrm{C}$ values intermediate to the $\mathrm{C}_{3}$ and $\mathrm{C}_{4}$ plants. However, except for $F$. brownii, the values were closer to the $\mathrm{C}_{3}$ extreme than the $\mathrm{C}_{4}$ extreme. In this study we have classified $F$. brownii as a $\mathrm{C}_{3}-\mathrm{C}_{4}$ species based on previous reports of incomplete compartmentation of $\mathrm{C}_{3}$ - and $\mathrm{C}_{4}$-cycle enzymes (Reed and Chollet 1985) and measurable oxygen inhibition of photosynthesis (Monson et al. 1987). The actual $\delta^{13} \mathrm{C}$ values for $\mathrm{C}_{3}-\mathrm{C}_{4}$ species were within $4 \%$ of the predicted values.

In order to obtain a broader perspective on how the $\delta^{13} \mathrm{C}$ values of $\mathrm{C}_{3}-\mathrm{C}_{4}$ Flaveria species should vary as a function of the proportion of atmospheric $\mathrm{CO}_{2}$ assimilated through the $\mathrm{C}_{3}$ or $\mathrm{C}_{4}$ pathways, theoretical calculations of $\delta^{13} \mathrm{C}$ over a range of values for $c$ and $d$ were conducted. When $\mathrm{CO}_{2}$ leakiness is zero, the $\delta^{13} \mathrm{C}$ value is predicted to increase from $-30.3 \%$ at $0 \% \mathrm{C}_{4}$ assimilation $\left(100 \% \mathrm{C}_{3}\right.$ assimilation), to $-17.4 \%$ at $50 \% \mathrm{C}_{4}$ assimilation, to $-4.6 \%$ at $100 \% \mathrm{C}_{4}$ assimilation $\left(0 \% \mathrm{C}_{3}\right.$ assimilation). If $\mathrm{CO}_{2}$ leakiness is 0.75 ( $75 \%$ of the atmospheric $\mathrm{CO}_{2}$ assimilated by the $\mathrm{C}_{4}$ cycle is not reassimilated by the $\mathrm{C}_{3}$ cycle following decarboxylation), the $\delta^{13} \mathrm{C}$ value is predicted to only increase from $-30.3 \%$ at $0 \% \mathrm{C}_{4}$ assimilation, to $-27.0 \%$ at $50 \% \quad \mathrm{C}_{4}$ assimilation, to $-23.8 \%$ at $100 \% \mathrm{C}_{4}$ assimilation. The predictions were made assuming an average pi/pa of 0.75 which is typical of $\mathrm{C}_{3}-\mathrm{C}_{4}$ Flaveria secies (Table $1)$. 
Table 2. $\delta^{13} \mathrm{C}$ values for leaves of several Flaveria species grown in a greenhouse and sampled at various times during the year

\begin{tabular}{llll}
\hline Species & Genotype & $\begin{array}{l}\text { Time of } \\
\text { Collection }\end{array}$ & $\delta^{13} \mathrm{C}(\% \mathrm{o})$ \\
\hline F. trinervia. & M2 & March & -15.3 \\
& K1 & July & $-14.5 \pm 0.1$ \\
F. cronquistii & K1 & July & $-28.0 \pm 0.3$ \\
F. brownii & MB6 & March & -17.7 \\
& MB6 & July & $-17.4 \pm 0.1$ \\
F. ramosissima & K1 & September & -28.1 \\
& K1 & April & -28.3 \\
& K1 & July & $-28.2 \pm 0.1$ \\
F. floridana & M1 & April & -27.1 \\
& M1 & July & $-28.3 \pm 0.1$ \\
F. pubescens & M1 & March & -32.1 \\
& K1 & July & $-28.8 \pm 0.2$ \\
F. linearis & M2 & September & -29.6 \\
& M1 & March & -30.6 \\
& M2 & April & -25.3 \\
& K1 & July & $-27.6 \pm 0.2$ \\
\hline
\end{tabular}

M-genotypes were obtained by Mets and grown at the University of Chicago; $\mathrm{K}$-genotypes were obtained by $\mathrm{Ku}$ and grown at Washington State University or the University of Colorado

All values not followed by \pm represent single measurements. Values followed by \pm represent the mean \pm SE of five replicate measurements

Measurements of $\delta^{13} \mathrm{C}$ were conducted at various times during the year on seven Flaveria species grown in a greenhouse (Table 2). The purpose of these measurements was to provide a larger range of samples to assess whether the values reported in Table 1 were truly representative of the species. The $\delta^{13} \mathrm{C}$ values of the greenhouse-grown plants were within $\pm 3 \%$ of the growth-chamber-grown plants, with an exception being the March value for $F$. pubescens, which was $4.2 \%$ more negative than the growth-chamber value.

\section{Discussion}

Two of the principal factors underlying $\mathrm{C}_{3}$-like $\delta^{13} \mathrm{C}$ values in the $\mathrm{C}_{3}-\mathrm{C}_{4}$ Flaveria species appear to be the $\mathrm{CO}_{2}$-leakiness value $\left(\emptyset_{2}\right)$ and the observed $\mathrm{pi} / \mathrm{pa}$ value. As calculated here, leakiness may be overestimated (see Farquhar 1983). In essence, the leakiness calculations involve comparing actual to theoretical quantum yields (the greater the difference, the greater the calculated leakiness). The calculations do not adequately account for potential reductions in quantum yield due to energy-requiring non-photosynthetic processes, or the absorption of light by non-photosynthetic pigments and molecules. Additionally, the quantum yield is dependent on the wavelength distribution of absorbed light, being higher in red light (Evans 1987). Thus, the quantum-yield values reported here, which were measured in white light, may not reflect the true energetic demands of $\mathrm{CO}_{2}$ assimilation through the $\mathrm{C}_{3}$ and $\mathrm{C}_{4}$ cycles. Finally, on theoretical grounds the leakiness values calculated from quantum yields measured at low light levels may differ from the values that exist at the higher light levels present during growth. For these reasons, the leakiness values and predicted $\delta^{13} \mathrm{C}$ values reported in Table 1 should be viewed as estimates.

Despite the potential problems in calculating leakiness, estimates of $\delta^{13} \mathrm{C}$ using the models described here are reasonably close to measured $\delta^{13} \mathrm{C}$ values (Table 1; Farquhar 1983). The calculated values of $\emptyset_{2}$ for the $C_{3}-C_{4}$ species are higher than those typically calculated for fully expressed $\mathrm{C}_{4}$ species (e.g. Farquhar 1983). The utility of the leakiness values reported in Table 1 is that they provide evidence, in a relative sense, of inefficiency in the transfer of carbon from the $\mathrm{C}_{4}$ pathway to the $\mathrm{C}_{3}$ pathway in the $\mathrm{C}_{3}-\mathrm{C}_{4}$ species. The models used in this study demonstrate that such inefficiency, when combined with $\mathrm{C}_{3}$-like pi/pa values, results in $\mathrm{C}_{3}$-like $\delta^{13} \mathrm{C}$ values in $\mathrm{C}_{3}-\mathrm{C}_{4}$ plants that assimilate up to $50 \%$ of their carbon through the $\mathrm{C}_{4}$ pathway. Leakiness in the $\mathrm{C}_{3}-\mathrm{C}_{4}$ Flaveria species may be a consequence, in large part, of incomplete compartmentation of enzymes involved in the $\mathrm{C}_{3}$ and $\mathrm{C}_{4}$ cycles (Bauwe 1984; Reed and Chollet 1985), and futile cycling of $\mathrm{CO}_{2}$ between carboxylation and decarboxylation events (see Discussion in Monson et al. 1986).

Through the models described earlier (see Theory section) and the leakiness values reported in Table 1, we calculated that, given equal pi/pa values, we should be able to detect differences of $3-4 \%$ in ${ }^{13} \mathrm{C}$ content when comparing values for fully expressed $\mathrm{C}_{3}$ species and $\mathrm{C}_{3}-\mathrm{C}_{4}$ species that assimilate between 40 and $50 \%$ of their carbon through the $\mathrm{C}_{4}$ pathway. We were not able to detect such a difference when comparing $F$. conquistii $\left(\mathrm{C}_{3}\right)$ with several $\mathrm{C}_{3}-\mathrm{C}_{4}$ species grown in growthchamber and greenhouse environments. Two principal factors could have operated to ameliorate the anticipated differences between the $\mathrm{C}_{3}$ and $\mathrm{C}_{3}-\mathrm{C}_{4}$ species. First, the predicted $\delta^{13} \mathrm{C}$ values were generated from the biochemical and physiological traits measured at one instant during the lifetime of the leaf. There is some evidence that traits such as leakiness of the bundle-sheath tissue, and the relative proportions of $\mathrm{C}_{3}$ - and $\mathrm{C}_{4}$-cycle activity can change as leaves mature in $F$. trinervia (Moore 
et al. 1986). Young leaves tend to exhibit a greater ratio of $\mathrm{C}_{3} / \mathrm{C}_{4}$ activity than mature leaves. Given that the $\delta^{13} \mathrm{C}$ value integrates the entire carbonassimilation history of the leaves (including any carbon imported from other leaves or organs), there is potential for instantaneous predictions to deviate considerably from actual biomass values. If there exists a lower potential for $\mathrm{C}_{4}$-cycle activity in young leaves of the $\mathrm{C}_{3}-\mathrm{C}_{4}$ species, the deviation between actual and predicted values in mature leaves would be such that the actual $\delta^{13} \mathrm{C}$ values are closer to the $\mathrm{C}_{3}$ value. Second, most of the $\mathrm{C}_{3}-\mathrm{C}_{4}$ Flaveria species exhibit slightly higher pi/pa values than $F$. cronquistii (Table 1). The higher $\mathrm{pi} / \mathrm{pa}$ values in the $\mathrm{C}_{3}-\mathrm{C}_{4}$ species would influence the $\delta^{13} \mathrm{C}$ values to become slightly more negative, once again bringing the $\mathrm{C}_{3}-\mathrm{C}_{4}$ values closer to the $\mathrm{C}_{3}$ value.

The relationship between measured $\delta^{13} \mathrm{C}$ values and ${ }^{14} \mathrm{C}$-incorporation into $\mathrm{C}_{4}$-acids (Table 1) may provide insight into the evolutionary relationship between the expression of the $\mathrm{C}_{4}$ pathway and the level of integration of carbon transfer between the $\mathrm{C}_{4}$ and $\mathrm{C}_{3}$ cycles. In this study, we define a high level of integration as a greater amount of atmospheric $\mathrm{CO}_{2}$ being assimilated by the $\mathrm{C}_{4}$ cycle and efficiently transferred to the $\mathrm{C}_{3}$ cycle following decarboxylation. In essence, a higher level of integration reflects a carbon-assimilation system that is less "open" (as defined in Berry and Troughton 1974). The less open system would result in less carbon-isotope discrimination by the $\mathrm{C}_{3}$ cycle. In the $\mathrm{C}_{3}-\mathrm{C}_{4}$ Flaveria species, it is assumed that the $\delta^{13} \mathrm{C}$ value is an index of biochemical integration, such that less negative values reflect more integration. The data presented in Table 1 demonstrate that among the Flaveria species an increase in expression of the $\mathrm{C}_{4}$ cycle from $0 \%$ to $50 \%$ of atmospheric $\mathrm{CO}_{2}$ fixation has occurred with no significant increase in integration between the $\mathrm{C}_{4}$ and $\mathrm{C}_{3}$ cycles. As the level of $\mathrm{C}_{4}$-cycle expression increases above $50 \%$ there is a sharp increase in the level of integration. This increased integration is apparently associated with further development of Kranz leaf anatomy and an improved compartmentation of $\mathrm{C}_{3}$ - and $\mathrm{C}_{4}$-cycle enzymes between mesophyll and bundle-sheath cells. Intuitively, it is reasonable to expect that there is an upper limit beyond which the evolution of increased activity of an inefficient, poorly integrated $\mathrm{C}_{4}$ cycle becomes energetically too costly, relative to the benefit it might provide (e.g. reduction of photorespiration). In the $\mathrm{C}_{3}-\mathrm{C}_{4}$ Flaveria species this limit appears to be at the $50 \%$ expression point, above which improved compartmentation and co-function of the $\mathrm{C}_{3}$ and $\mathrm{C}_{4}$ cycles must occur before further increases in $\mathrm{C}_{4}$ expression are possible.

We thank D. Schoeller (University of Chicago) for providing lab facilities and helpful discussion. Thanks are also due to G. Edwards and B. Moore (Washington State University, Pullman, USA), M. O'Leary (University of Wisconsin, Madison, USA), and S. von Caemmerer (Australian National University, Canberra) for helpful comments during the preparation of the manuscript. The authors assume full responsibility for its final form. This research was supported by National Science Foundation grants BSR-8407488 to R.K.M. and DEB-80-21270 to J.A.T, and a DeKalb-Pfizer Genetics, Inc, grant to J.A.T.

\section{References}

Bassüner, B., Keerberg, O., Bauwe, H., Pyarnik, T., Keerberg, H. (1984) Photosynthetic $\mathrm{CO}_{2}$ metabolism in $\mathrm{C}_{3}-\mathrm{C}_{4}$ intermediate and $\mathrm{C}_{4}$ species of Flaveria (Asteraceae). Biochem. Physiol. Pflanz. 179, 631-632

Bauwe, H. (1984) Photosynthetic enzyme activities and immunofluorescence studies on the localization of ribulose 1,5 -bisphosphate carboxylase/oxygenase in leaves of $C_{3}$, $\mathrm{C}_{4}$, and $\mathrm{C}_{3}-\mathrm{C}_{4}$ intermediate species of Flaveria (Asteraceae). Biochem. Physiol. Pflanz. 179, 253-268

Berry, J.A., Troughton, J.H. (1974) Carbon isotope fractionation by $\mathrm{C}_{3}$ and $\mathrm{C}_{4}$ plants in "closed" and "open" atmospheres. Carnegie Instn. Washington Yearb. 73, 785-790

Edwards, G.E., Ku, M.S.B. (1988) Biochemistry of $\mathrm{C}_{3}-\mathrm{C}_{4}$ intermediates. In: The biochemistry of plants: A comprehensive treatise, vol. 14: Photosynthesis, Hatch, M.D., and Boardman, N.K., eds. Academic Press, New York (in press)

Ehleringer, J., Björkman, O. (1977) Quantum yields for $\mathrm{CO}_{2}$ uptake in $\mathrm{C}_{3}$ and $\mathrm{C}_{4}$ plants. Dependence on temperature, $\mathrm{CO}_{2}$ and $\mathrm{O}_{2}$ concentration. Plant Physiol. 59, 86-90

Ehleringer, J., Pearcy, R.W. (1983) Variation in quantum yield for $\mathrm{CO}_{2}$ uptake among $\mathrm{C}_{3}$ and $\mathrm{C}_{4}$ plants. Plant Physiol. 73, 555-559

Evans, J.R. (1987) The dependence of quantum yield on wavelength and growth irradiance. Aust. J. Plant Physiol. 14, 69-79

Farquhar, G.D. (1983) On the nature of carbon isotope discrimination in $\mathrm{C}_{4}$ species. Aust. J. Plant. Physiol. 10, 205-226

Farquhar, G.D., O'Leary, M.H., Berry, J.A. (1982) On the relationship between carbon isotope discrimination and the intercellular carbon dioxide concentration in leaves. Aus. J. Plant. Physiol. 9, 121-137

Gurevitch, J., Teeri, J.A., Wood, A.M. (1986) Differentiation among populations of Sedum wrightii (Crassulaceae) in response to limited water availability: water relations, $\mathrm{CO}_{2}$ assimilation, growth and survivorship. Oecologia 70, 198-204

Holaday, A.S., Chollet, R. (1984) Photosynthetic/photorespiratory characteristics of $\mathrm{C}_{3}-\mathrm{C}_{4}$ intermediate species. Photosynth. Res. 5, 307-323

Holaday, A.S., Lee, K.W., Chollet, R. (1984) $\mathrm{C}_{3}-\mathrm{C}_{4}$ intermediate species in the genus Flaveria: leaf anatomy, ultrastructure, and the effect of $\mathrm{O}_{2}$ on the $\mathrm{CO}_{2}$ compensation concentration. Planta 160, 25-32

Keeling, C.D., Mook, W.G., Tans, P.P. (1979) Recent trends in the ${ }^{13} \mathrm{C} /{ }^{12} \mathrm{C}$ ratio of atmospheric carbon dioxide. Nature 277, 121-123

$\mathrm{Ku}$, M.S.B., Monson, R.K., Littlejohn, R.O., Nakamoto, H., Fisher, D.B., Edwards, G.E. (1983) Photosynthetic charac- 
teristics of $\mathrm{C}_{3}-\mathrm{C}_{4}$ intermediate Flaveria species. I. Leaf anatomy, photosynthetic responses to $\mathrm{O}_{2}$ and $\mathrm{CO}_{2}$ and activities of key enzymes in the $\mathrm{C}_{3}$ and $\mathrm{C}_{4}$ pathways. Plant Physiol. 71, 944-948

Monson, R.K., Edwards, G.E., Ku, M.S.B. (1984) $C_{3}-C_{4}$ intermediate photosynthesis in plants. BioScience 34, 563-574

Monson, R.K., Littlejohn, R.O., Williams, G.J. (1982) The quantum yield for $\mathrm{CO}_{2}$ uptake in $\mathrm{C}_{3}$ and $\mathrm{C}_{4}$ grasses. Photosynth. Res. 3, 153-159

Monson, R.K., Moore, B.D., Ku, M.S.B., Edwards, G.E. (1986) Co-function of $\mathrm{C}_{3}$ - and $\mathrm{C}_{4}$-photosynthetic pathways in $\mathrm{C}_{3}, \mathrm{C}_{4}$, and $\mathrm{C}_{3}-\mathrm{C}_{4}$ intermediate Flaveria species. Planta 168, 493-502

Monson, R.K., Schuster, W.S., Ku, M.S.B. (1987) Photosynthesis in Flaveria brownii A.M. Powell. A $\mathrm{C}_{4}$-like $\mathrm{C}_{3}-\mathrm{C}_{4}$ intermediate. Plant Physiol, 85, 1063-1067

Moore, B.D., Cheng, S.-H., Edwards, G.E. (1986) The influence of leaf development on the expression of $\mathrm{C}_{4}$ metabolism in Flaveria trinervia, a $\mathrm{C}_{4}$ dicot. Plant Cell Physiol. 27, 1159-1167

O'Leary, M.H. (1981) Carbon isotope fractionation in plants. Phytochemistry 20, 553-567

Peisker, M. (1985) Modelling carbon metabolism in $\mathrm{C}_{3}-\mathrm{C}_{4}$ in- termediate species. 2. Carbon isotope discrimination. Photosynthetica 19,300-311

Powell, A.M. (1978) Systematics of Flaveria (Flaveriinae-Asteraceae). Ann. Mo. Bot. Gard. 65, 590-636

Reed, J.E., Chollet, R. (1985) Immunofluorescent localization of phosphoenolpyruvate carboxylase and ribulose 1,5-bisphosphate carboxylase/oxygenase proteins in leaves of $\mathrm{C}_{3}$, $\mathrm{C}_{4}$, and $\mathrm{C}_{3}-\mathrm{C}_{4}$ intermediate Flaveria species. Planta 165 , 439-445

Roeske, C.A., O'Leary, M.H. (1984) Carbon isotope effects on the enzyme-catalyzed carboxylation of ribulose bisphosphate. Biochemistry 23, 6275-6284

Rumpho, M.E., Ku, M.S.B., Cheng, S.H., Edwards, G.E. (1984) Photosynthetic characteristics of $\mathrm{C}_{3}-\mathrm{C}_{4}$ intermediate Flaveria species. III. Reduction of photorespiration by a limited $\mathrm{C}_{4}$ pathway of photosynthesis in Flaveria ramosissima. Plant Physiol. 75, 993-996

Smith, B.N., Powell, A.M. (1984) $\mathrm{C}_{4}$-like $\mathrm{F}_{1}$-hybrid of $\mathrm{C}_{3} \times \mathrm{C}_{4}$ Flaveria species. Naturwissenschaften 71, 217-218

Smith, B.N., Turner, B.L. (1975) Distribution of Kranz syndrome among Asteraceae. Am. J. Bot. 62, 541-545

Received 27 March; accepted 12 October 1987 